\title{
Narracje głodu czy narracje o głodzie?
}

\begin{abstract}
Brejnak Sebastian, Narracje głodu czy narracje o głodzie? [Hunger's Narrative or Narratives of Hunger?]. „Przestrzenie Teorii” 33. Poznań 2020, Adam Mickiewicz University Press, pp. 283-302. ISSN 1644-6763. DOI 10.14746/pt.2020.33.14.

The aim of this article is to enumerate the main types of discourses in which the phenomenon of hunger is represented. These are following: culture of hunger (an anthropological and ethnological term describing cultural formations based on the problem of famine), politics of hunger (starvation used for political reasons), poetics of hunger (hunger as a component of a piece of art). The question about the difference between the presence of hunger (hunger's narrative) and the representation of hunger (narrative of hunger) is the main problem of this essay. Brejnak claims that on the one hand, there is no unnarrated hunger (a natural/pure hunger) in cultural communication. On the other hand, he underlines that the experience of hunger as such is non-transitive and verbally inexpressible.
\end{abstract}

KEYWORDS: hunger, narrative, culture, politics, poetics

\section{Wprowadzenie}

Trudno mi to pogodzić z dobrymi bogami.

Chyba że łatwowierni,

chyba że naiwni,

całą władzę nad światem oddali naturze.

I to ona, szalona, narzuca nam głód,

a tam gdzie głód,

tam koniec niewinności.

Do głodu dołączają się natychmiast zmysły:

smak, powonienie i dotyk, i wzrok,

bo nie jest obojętne, jakie sa potrawy

i na jakich talerzach.

Nawet słuch bierze udział

w tym, co się odbywa,

bo przy stołach nierzadko wesołe rozmowy ${ }^{1}$.

Wisława Szymborska w przytoczonym wyżej wierszu mówi o polisensoryczności doświadczeń związanych z jedzeniem oraz konsolidującym wspólnotę aspekcie uczestniczenia w biesiadzie. Platoński sympozjon - uprawiany jako forma zarazem cielesnej rozkoszy, jak i niebagatelnej gimnastyki

${ }^{1}$ W. Szymborska, Przymus, [w:] tejże, Wystarczy, Kraków 2012. 
umysłu - uznać można z pewnością za protoplastę dzisiejszych „wesołych rozmów" w trakcie posiłku, w czasie których rozprawia się nie tylko o spożywanych potrawach, ale również (a może: przede wszystkim) na tematy daleko wybiegające poza zawartość biesiadnego stołu. Współczesne convivium philosophicum, niekoniecznie skupiające się wokół dylematów filozoficznych, jest więc nieodłącznym komponentem kultury codzienności, wpływającym na kształt relacji uczestników kulturowego polilogu. Czy można jednak wytworzyć kulturę nie wokół rytuałów zaspokajania głodu, lecz wobec samego głodu - tego, co pozornie przynależy wyłącznie do sfery natury (,szalonej” natury $)^{2}$, co oznacza „przymus”, „koniec niewinności”? Czy można głód opowiedzieć albo wypowiedzieć się w jego imieniu?

$\mathrm{W}$ niniejszym szkicu postaram się przedstawić trzy podstawowe modusy, w jakich głód - w postaci zdenaturalizowanej, pozbawionej semantycznej neutralności - może się przejawiać i, dosłownie, przemawiać w przestrzeni kulturowej komunikacji ${ }^{3}$ (albo: być omawianym w owym polu). Chciałbym więc na wstępie wymienić umowne płaszczyzny narracji głodu/narracji o głodzie ${ }^{4}$, którym w tym studium przyjrzę się bliżej. Będą to:

a) kultura głodu - termin używany przez antropologów i etnologów na określenie formacji kulturowych zorganizowanych wokół problemu głodu;

b) polityka głodu - głód wykorzystywany do celów ideologicznych (jako strategiczne narzędzie władzy);

c) poetyka głodu - głód jako komponent tematyczny dzieła sztuki (w tym szkicu: dzieła literackiego), główny problem lub podmiot dyskursu artystycznego.

\section{Kultura głodu}

Trudno nie zgodzić się ze stwierdzeniem, że określenie „kultura głodu” brzmi oksymoronicznie, a przynajmniej paradoksalnie. Połączenie „głodu” jako synonimu braku, niedostatku, pustki z „kultura” - tym, co kojarzy się z naddatkiem (sensu, wartości, materialnej jakości), innowacyjnościa, jest

${ }^{2} \mathrm{O}$ możliwości zaistnienia kultury skoncentrowanej wokół postu/ascezy oraz wstrętu wobec jedzenia, pisał m.in. Piero Camporesi w Laboratoriach zmysłów (P. Camporesi, Laboratoria zmysłów, przeł. J. Ugniewska, Gdańsk 2005, s. 79-110).

${ }^{3}$ Chodzi tu o szeroką definicję kultury pojmowanej jako wszelki rodzaj działalności człowieka niezwiązany z naturalnymi powinnościami.

${ }^{4}$ Rozróżnienie to odnosi się do relacji między prezentacją (uobecnieniem) a reprezentacją w tekście kultury (zob. np. H.U. Gumbrecht, Produkcja obecności: czego znaczenie nie może przekazać, przeł. K. Hoffmann, W. Szwebs, Poznań 2016; M.P. Markowski, O reprezentacji, [w:] Kulturowa teoria literatury. Główne pojęcia i problemy, red. M.P. Markowski, R. Nycz, Kraków 2006). 
wyraźnie dysonansowe, trudne do intuicyjnego zaakceptowania. Powszechnie mówi się raczej o „kulturze jedzenia” jako savoir-vivrze spożywania/ podawania posiłków i zachowania przy stole. Antropologiczno-etnologiczne dwudziestowieczne studia dotyczące codziennego życia, tzw. kultur pierwotnych, posługują się jednak od lat terminologia, w której występuje owo paradoksalne zespolenie „kultury” i „głodu”. Amerykańska badaczka Sharman Apt Russell w Gtodzie. Historii nienaturalnej, w rozdziale zatytułowanym Antropologia głodu, przywołuje je w kontekście obserwacji Guragów - ludności osiadłej w południowo-wschodniej Etiopii:

Para badaczy zaobserwowała u Guragów cechy, które ich zdaniem wiązały się ściśle z tzw. kulturą głodu. Ludzie tej grupy byli „samolubni” i starannie kalkulowali, jakiej wzajemności będzie od nich wymagał każdy podarunek. Utrzymywali emocjonalną rezerwę wobec członków rodziny i postrzegali relacje międzyludzkie jako układ zobowiązań ${ }^{5}$.

William i Dorothy Shackowie, badając ludność Gurage w latach 60. XX wieku, zauważyli, że przedstawiciele tej grupy - na skutek doświadczeń wieloletniego głodu (spowodowanego przede wszystkim wojnami) - wypracowali model kultury „samolubności”, objawiającej się chociażby w nadmiarowym gromadzeniu żywności czy wypracowaniu rygorystycznych zasad niegościnnościniedzielenia się zapasami z innymi członkami społeczności (także: rodziny). W kulturze Guragów waloryzowana była także radykalna wstrzemięźliwość (wpajana już od niemowlęctwa), za wyjątkiem comiesięcznych pokazowych ceremonii obżarstwa lub stanów choroby (w czasie których „pacjent nakrywał się pledem i wpychał sobie do ust specjalnie przygotowaną potrawę" $\left.{ }^{\prime}\right)$.

Inny antropolog - Michael Young - opisywał w latach 70. ubiegłego wieku zwyczaje ludu Kalauna w Papui-Nowej Gwinei, który, podobnie jak Gurage, pielęgnował ascetyczny tryb życia i anorektyczny ideał cielesności. $\mathrm{W}$ trakcie specjalnych rytuałów magicznych plemienny czarownik przechadzał się po ogródkach warzywnych, patrząc na zbiory „«niepożądliwym wzrokiem», obojętnym wobec obfitości plonów”. Ten sam mag mógł w ramach rytuału „walki z głodem” rzucić na członków plemienia klątwę łakomstwa. Ofiara takiego zaklęcia zmuszana była do niepohamowanej żarłoczności, prowadzącej w konsekwencji do śmierci z przejedzenia ${ }^{8}$.

Inny badacz - Colin Turnbull - badał w latach 60. kulturę Ików zamieszkujących północną część granicy między Ugandą i Kenią którym

${ }^{5}$ S. Apt Russell, Głód. Historia nienaturalna, przeł. K. Orszulewska, Warszawa 2011, s. 139. Wszystkie wyróżnienia - moje.

${ }^{6}$ Tamże, s. 138.

7 Tamże, s. 139.

${ }^{8}$ Zob. tamże, s. $139-140$. 
na początku XX wieku zakazano polowań na terenie parku narodowego w zamian za co przydzielono im kawałki nieurodzajnej ziemi. Zdaniem Turnbulla, wieloletni głód wpłynął na wytworzenie się wśród Ików kultury radykalnego egoizmu:

Przez pierwsze dwa lata pełna złości i niechęci matka karmiła swoje niemowlę. W trzecim roku dziecko było odstawiane od piersi w ramach celowego emocjonalnego i fizycznego zrywania więzi [...]. Trzylatki wyrzucano z domu, wolno im było tylko nocować pod drzwiami. Zupełnie same, pozbawione pożywienia i schronienia, dołączały do gangów złożonych z innych dzieci w wieku 7-8 lat. Jeśli udawało im się przeżyć kilka kolejnych lat, wyszukując jedzenie lub kradnąc z pól i ogrodów, dołaczały do kolejnego gangu starszych dzieci, zdolnych już do wspinania się na dzikie figowce. W wieku 12 czy 13 lat osiagały dojrzałość i mogły samodzielnie poszukiwać żywności [...]. Sędziwi Ikowie, podobnie jak osoby schorowane, nie otrzymywali pokarmu, aż w końcu umierali. Zazwyczaj sami czołgali się do opuszczonych chat, gdzie w samotności konali z głodu9 .

Wypracowane przez Ików w ciagu dekad normy (przez przedstawiciela kultury europejskiej nazwane raczej anomaliami), takie jak: brak empatii czy ekstremalna egoistyczność, łączące się z przymusem samowystarczalności, stały się jedynie obowiąujaccym programem ich kultury. Epicentrum takiego modelu codziennego funkcjonowania stanowi głód - rozumiany już nie jako neutralna potrzeba fizjologiczna, która należy zaspokoić, żeby przetrwać, lecz również jako najważniejszy czynnik kształtujący społeczne nakazy i zakazy, obyczaje i sposoby działania, poza które nie można wyjść. O szybkości naturalizowania się określonych reguł kultury Ików przekonał się na własnej skórze sam Turnbull, który przyznał, że po miesiącach przebywania wśród Afrykańczyków, przestał przejmować się losem głodujących: „[...] nagle zdałem sobie sprawę, że w ogóle nie dbam o tych ludzi. Kiedy umierali, zapełniałem po prostu notes zapiskami»" 10 . Co więcej, z czasem zaczął również podzielać uczucie sadystycznej przyjemności z nieszczęścia innych, które jest jednym z wyznaczników Ikowskiej kultury (,Turnbull pisał, że odczuwał swoistą przyjemność, słuchając krzyków dziecka"11).

Mimo że antropolog po powrocie z badań nazwał organizację życia Ików „chorobliwa” i „potworna”, to nie odmówił jej statusu kulturotwórczego. Etnologicznie pojmowana kultura głodu, choć opiera się na wartościach powszechnie uznawanych za antykulturowe (w znaczeniu: antywspólnotowe, uniemożliwiające partycypację), ma więc prawo bytu, ale jedynie pod warunkiem, że pojmuje się ją rzeczownikowo, zatem, jak podaje Ryszard Nycz, jako

\footnotetext{
${ }^{9}$ Tamże, s. 140-141.

${ }^{10}$ Cyt. za: tamże, s. 143.

${ }^{11}$ Tamże.
} 
uporządkowany świat wartości i sensu, w który jednostka wkracza, którego się uczy, który zakreśla granice możliwego/stosownego/gratyfikującego i niemożliwego/niestosownego/tabuizowanego, który rozpościera przed nią wachlarz nacechowanych wartościująco scenariuszy zachowaniowych, system zakazów i nakazów, symboliczne uniwersum tożsamościowej przynależności oraz terytoria ubi leones, obcości czy inności ${ }^{12}$.

Dodać należy, że tak ujęta „kultura głodu” najczęściej jest mimowolnym wytworem (czy raczej: nowotworem) oficjalnej polityki/ideologii państwowej. W przypadku ludu Kalauna, Guragów i Ików powodem powstania „scenariuszy zachowaniowych", w których główną rolę odgrywał głód, były zarówno przyczyny naturalne (nieurodzaj, klęski żywiołowe), jak i polityczne (wojny oraz zakaz polowań w przypadku Ików).

Inaczej kształtowała się kultura głodu ludności zamieszkującej chiński region Anhui, która padła ofiarą dyktatury Mao Zedonga, dążącego do nieracjonalnego uprzemysłowienia kraju (kosztem rolnictwa). W przypadku Chińczyków fundamentem nowej kultury (nowokultury? pseudokultury?), narosłej na ideologii komunistycznej, był handel własnymi dziećmi oraz kanibalizm ${ }^{13}$ :

Jak przedstawia to Becker [Jasper Becker, autor książki Hungry Ghosts - przyp. S.B.]: „Ogólnie rzecz biorąc, wieśniacy żywili się trupami, zwłaszcza trupami dzieci. W rzadkich przypadkach rodzice zjadali własne potomstwo, starsi bracia młodszych braci, starsze siostry młodsze siostry". W regionie Anhui ludzie nadal używali porzekadła: Yi ze er shi, czyli: „Zamień się dziećmi, zrób jedzenie”. Jeden z rozmówców Beckera opisywał, jak „przestawali dawać dzieciom pokarm. Dawali tylko wodę. Wymienili ciało córki na dziecko sasiada. Ze zwłok gotowali potem rodzaj zupy. Ludzie nauczyli się tego w latach 30. Przyjmowali to za swoistą kulturę głodu ${ }^{14}$.

Przymus - tytuł cytowanego na samym początku wiersza Szymborskiej jest być może słowem najlepiej streszczającym cechy tak powstałej kultury z przenicowanymi wartościami (antykultury / kultury na opak / kultury w cudzysłowie). Ten natomiast, zdaniem poetki, stoi po stronie „szalonej” natury. Trudno jednak zrzucić cały ciężar odpowiedzialności na czynniki naturalne, takie jak: klęski żywiołowe, które jako takie nie prowadzą przecież do powstania jakichkolwiek trwalszych formacji kulturowych (zbudowanych na konkretnych rytuałach, normach, wzorcach zachowania). Prawie zawsze ów przymus ma, jak starałem się dotąd udowodnić, podłoże polityczne i jest

${ }^{12}$ R. Nycz, Kultura jako czasownik. Sondowanie nowej humanistyki, Warszawa 2017, s. 66 .

${ }^{13} \mathrm{Na}$ problem kanibalizmu zwróciła też uwagę Agnieszka Holland w filmie Obywatel Jones (2019) dotykającym problemu Hołodomoru (w jednej ze scen głodujący Ukraińcy spożywają potrawę sporządzoną ze szczątków członka własnej rodziny).

${ }^{14}$ S. Apt Russell, dz. cyt., s. 148. 
skutkiem ubocznym antyantropologicznej (nieukierunkowanej na potrzeby człowieka; potocznie: nieludzkiej) strategii państwa. Opór wobec tej strategii staje się aktem nieposłuszeństwa wobec machiny władzy, zarazem wobec własnego kulturowego usytuowania. Jest o tyle trudniejszy, że dotyczy głodn e go - jednostki skrajnie - fizycznie i psychicznie - wycieńczonej.

Antropolożka Nancy Scheper-Hughes, zajmująca się problemem głodu wśród brazylijskich robotników na plantacjach trzciny cukrowej (w latach 60 . ubiegłego stulecia), zwraca uwagę na konieczność wyrozumiałości wobec mimowolnych uczestników tak rozumianej kultury głodu. Stara się pojąć konieczność obojętności brazylijskich matek w stosunku do ich umierających z głodu dzieci. Macierzyństwo, diametralnie przewartościowane w pryzmacie kultury głodu, oznaczało bowiem w Alto de Cruzeiro, nie bezgraniczną opiekę i troskę, lecz wiedzę „kiedy opuścić dziecko, które «pokazuje», że chce umrzeć” ${ }^{15}$. „W tej kulturze głodu matczyną miłość i więź odkładano na później, do momentu, kiedy dziecko udowodni, że jest silne i chce żyć”"16.

\section{Polityka głodu}

Nietrudno zauważyć, że opisane wyżej nieeuropejskie „kultury głodu” wytworzyły się przede wszystkim na skutek działań politycznych. Warto przyjrzeć się pokrótce temu, jak na Starym Kontynencie głód stawał się orężem dyskryminacji i politycznego ucisku. Na początku trzeba nadmienić, że głód w rodzącej się w końcu XVII wieku epoce Oświecenia był nadal problemem niewygodnym, umyślnie wypieranym przez oficjalny głos władzy, owijanym „płaszczem sytości”, który miał sprawić, że dla społeczeństwa stanie się tematem przezroczystym. Tadeusz Sławek w cyklu liryków poświęconych zagadnieniu głodu tak ują ów mechanizm zatajania głodu napędzający nowoczesne teorie postępu (o proweniencji oświeceniowej: Condorcetowsko-Turgotowskiej):

Głód ukradł tajemnicę pustki, wielkiej

otwartej łupiny boskiego orzecha;

za karę przykuli go do skały

i sęp wydziobuje mu wątrobę ${ }^{17}$.

Głód paradoksalnie dzieli więc los jednego z patronów europejskiego Oświecenia - Goethowskiego Prometeusza - figury nieskończonej ludzkiej inwencyjności, tylko dlatego że odsłania „tajemnicę pustki” wielkiego

\footnotetext{
${ }^{15}$ Tamże, s. 151.

${ }^{16}$ Tamże.

${ }^{17}$ T. Sławek, Narodziny, [w:] tegoż, O głodzie: wiersze, Katowice 1994, s. 29.
} 
planu rodzącej się nowoczesności ${ }^{18}$. Pieczołowicie skrywanym sekretem okazuje się głos głodujących, nijak harmonizujący się z oświeceniową melodia optymizmu poznawczego. Krzyk wykluczonych, zagłuszany peanami na cześć człowieczego rozumu, zdołał jednak usłyszeć Jonathan Swift i dał temu wyraz w A Modest Proposal. Tak rozpoczynał autor Podróży Guliwera swoją polityczną satyrę Skromna propozycja opatrzona podtytułem Co zrobić, by dzieci biedaków nie byty ciężarem dla swych rodziców lub kraju:

Smętny to obraz dla tych, co spacerując po naszym wielkim mieście, lub po kraju podróżując, widzą ulice, gościńce i drzwi chat zapełnione tłumem żebrzących niewiast, za którymi postępuje po troje, czworo albo i sześcioro dzieci, a wszyscy w łachmanach i o jałmużnę przechodnia każdego nagabują. Nie mogąc uczciwą pracą bytu im zapewnić, matki te zmuszone są bezustannie wędrować, upraszając o wspomożenie bezbronnych dziatek, które, gdy dorosna, z braku zatrudnienia złodziejami się stają lub porzucaja drogi nasz kraj, by w Hiszpanii za Pretendenta walczyć albo sprzedają się na Barbados ${ }^{19}$.

Swift prowadzi swoją narrację tak, jakby konstruował ją londyński polityk zainteresowany wyłącznie pilnowaniem własnego stołka w parlamencie. Przedstawia zatem wzór „ostatecznego rozwiązania kwestii irlandzkiej”, gdyby posłużyć się parafrazą eufemistycznego określenia użytego w czasie konferencji w Wannsee dwa wieki później w odniesieniu do Żydów. W obu przypadkach chodzi o eksterminację niewygodnej dla państwa z różnych względów części społeczeństwa. W Skromnej propozycji jest nią biedota irlandzka, która nie tylko negatywnie wpływa na oświeceniowy wizerunek imperialnego Królestwa Wielkiej Brytanii, lecz również stanowi poważne obciążenie dla skarbu państwa. Toteż idealnym - idąc za tropem racjonalistycznych wzorców Oświecenia - rozwiązaniem byłoby, jak można przeczytać w satyrze Swifta, nie tylko pozbycie się głodujących, ale także zrobienie z nich pożytku (wedle nakazów utylitaryzmu). Nieproduktywna dla polityki kraju grupa Irlandczyków powinna więc stać się towarem dającym się skonsumować, również w znaczeniu dosłownym:

Pewien dobrze znający się na rzeczy Amerykanin, mój znajomy z Londynu, zapewnił mnie, że młodziutkie i zdrowe, dobrze odżywione roczne dziecko wielce jest smakowitym i nader pożywnym pokarmem, zarówno duszone w jarzynach, jak pieczone, smażone czy gotowane, z czego wnoszę, że nadaje się także dla przyrządzenia gulaszu albo potrawki ${ }^{20}$.

${ }^{18}$ Zob. Z. Bauman, Nowoczesność i zagłada, przeł. F. Jaszuński, Warszawa 1992; M. Foucault, Czym jest Oświecenie?, [w:] tegoż, Filozofia, historia, społeczeństwo, przeł. D. Leszczyński, L. Rasiński, Warszawa 2000.

${ }^{19}$ J. Swift, Skromna propozycja, przeł. E. Krasińska, „Dialog” 2013, 1, s. 127-129.

${ }^{20}$ Tamże. 
Swift, wcielając się w rolę idealnego oświeceniowego polityka, posługuje się więc empatycznie wyzerowanym, zdroworozsądkowym i do cna pragmatycznym dyskursem, opartym na skrupulatnych wyliczeniach oraz optymistycznej logice zysków i szans dalszego rozwoju (niechybnie prowadzącego do politycznego sukcesu):

Pozwalam sobie przeto pokornie podać ogółowi pod rozwagę propozycję, aby z owych wyliczonych wcześniej stu dwudziestu tysięcy dzieci dla dalszego rozrodu zachować dwadzieścia tysięcy, z czego jedną czwartą stanowiłyby dzieci płci męskiej, czyli więcej niż się normalnie stosuje w hodowli owiec, bydła rogatego czy świń, a to przez wzgląd na to, że dzieci te są po większej części spłodzone poza małżeństwem, tę bowiem okoliczność nasi barbarzyńcy za nic sobie maja, tedy jeden samiec wystarczy dla obsłużenia czterech samic. Pozostałe sto tysięcy dzieci, kiedy osiagna jeden rok życia, można oferować na sprzedaż co dostojniejszym a bogatszym obywatelom królestwa, przykazawszy matkom, aby w ostatnim miesiącu obficie karmiły maleństwa piersia, a to dla dodania im pulchności i tłustości przed pójściem na stół. Na przyjęcie w gronie przyjaciół z jednego dziecka dwa dania mieć można, a gdy rodzina sama do stołu zasiada, zadnia i przednia część na grzeczny wystarczą posiłek, zaś przyprawione odrobiną soli i pieprzu na czwarty dzień, specjalnie w zimie, najlepsze będa, kiedy je ugotować ${ }^{21}$.

Choć Swiftowska krytyka była szeroko komentowana przez ówczesna opinię publiczna, to trudno stwierdzić, że rzeczywiście przyczyniła się do zmiany w myśleniu angielskich polityków wieku rozumu i ich następców. Wielki Głód w Irlandii, który miał miejsce w połowie wieku XIX (a więc ponad sto lat po publikacji Skromnej propozycji), spowodowany zaraza Phytophthora infestans (niszczącej uprawy ziemniaka - podstawę wyżywienia Irlandczyków), okazał się dla angielskich elit niezdanym testem europejskiego humanitaryzmu (idei kiełkującej na początku XIX wieku przede wszystkim we Francji) ${ }^{22}$. Klęska głodu przez cztery lata (1845-1849) pochłonęła około półtora miliona ludzi. W newralgicznym momencie zarazy (w 1846 roku) Wielka Brytania pozostająca w unii z Irlandią nie udzieliła głodującym należytej pomocy ${ }^{23}$. Ta decyzja rządu brytyjskiego (którą można by dziś interpretować w kontekście pojęcia sepizacji - frazy somebody else’s problem jako określenia ponowoczesnej kultury obojętności ${ }^{24}$ ) była zarazem cichym przyzwoleniem na eksterminację Irlandczyków, o jakiej traktowała satyra Swifta.

${ }^{21}$ Tamże.

${ }_{22}$ Zob. M. Barnett, Empire of Humanity: a History of Humanitarianism, London 2011, s. $34-37$.

${ }^{23}$ Zob. P. Hamera, Wielki Głód w Irlandii 1845-1852 w świetle prasy angielskiej, Kraków 2016, s. 62.

${ }^{24}$ Temin „SEP” pochodzi z powieści Douglasa Adamsa Life, the Universe and Everything (1982). 
Zatarg między Wielką Brytanią a Irlandia, dla którego rozwoju owa pasywność Brytyjczyków w połowie XIX wieku nie pozostawała bez znaczenia, osiagną swoje apogeum na początku XX wieku w postaci wojny domowej wywołanej przez dążące do pełnej autonomii Irlandii ugrupowanie IRA (Irlandzką Armią Republikańska). Organizacja ta działała w różnych formach przez cały wiek XX, a oficjalny rozejm między stronami został zawarty dopiero w 2005 roku $^{25}$. Głód powraca więc w kontekście irlandzko-brytyjskich stosunków politycznych jak widmo, którego nie da się nijak wypędzić, wyprzeć z pamięci.

O tym, jak bardzo głód jest narażony na próby wymazania z historii wygumkowania z pola widzenia ${ }^{26}$ - niech świadczy fotoreportaż duńskiego imigranta Jacoba Riisa z 1888 roku How the Other Half Lives: Studies among the Tenements of New York ${ }^{27}$, majacy na celu uświadomienie ówczesnym mieszkańcom Nowego Jorku problemu miejskiej biedoty. Nieświadomość warunków życia głodującej „drugiej połowy” społeczeństwa - sasiadów nowojorczyków może napawać zdumieniem. Obiektyw aparatu Riisa wyzwolił nieistniejące wcześniej obrazy slumsów, zamieszkiwanych głównie przez imigrantów. Fotograficzne reprezentacje biedoty, obecnej niepokojąco blisko, po sasiedzku, stały się wstydliwym znakiem obojętności mieszkańców drugiej (,lepszej”) połowy Nowego Jorku wobec cierpienia Innego. Milcząca obecność głodu, lokująca się gdzieś po drugiej stronie tych obrazów, za uśmiechniętymi do obiektywu twarzami głodujących, miała już nigdy nie dawać spokoju patrzącym na fotografie, szczypaće ${ }^{28}$ ich w oczy, nawoływać do (przeciw)działania - stawiania kontrpropozycji rzeczywistości podzielonej na dwa obozy - sytych i głodujących.

Warto w tym miejscu napomknąc o dwudziestowiecznych losach ideologii głodu. Najbardziej ekstremalnym jej przejawem było wykorzystanie głodu (ściśle mówiąc: głodzenia) jako jednej z broni masowej zagłady, przede wszystkim w czasie II wojny światowej przez hitlerowskie Niemcy (poprzez Hungerplan, obozy koncentracyjne i getta ${ }^{29}$ ) oraz przez ZSRR

${ }^{25}$ W tym miejscu warto wspomnieć o filmie Steve'a McQueena z 2008 roku Gtód, w którym opowiedziana zostaje historia strajku głodowego irlandzkich więźniów domagających się statusu więźniów politycznych. Akcja filmu rozgrywa się w 1981 roku w północnoirlandzkim więzieniu Maze. Głównym bohaterem jest przywódca IRA - Bobby Sands, który zmarł po 66 dniach strajku głodowego.

${ }^{26}$ Por. z Widokiem cudzego cierpienia Susan Sontag.

${ }^{27}$ J. Riis, How the Other Half Lives: Studies among the Tenements of New York, Whitefish 2004.

${ }^{28}$ Por. z etymologią angielskiego hunger, w której pojawia się również określenie „,szczypania" (zob. podsumowujący podrozdział Gtodne kawatki).

${ }^{29}$ Istotnym świadectwem tej zbrodni jest polski dokument: Choroba głodowa. Badania kliniczne nad gtodem wykonane $w$ getcie warszawskim w roku 1942 (wydany w Warszawie w $1946 \mathrm{roku})$. 
na Ukrainie w latach 1932-1933, a także w polityce łagrowej i obozów głodowych praktykowanej również po wojnie. Dziś owa ideologia totalitarna przeszła, według wielu badaczy ${ }^{30}$, w inny stan skupienia, stając się jednym z podstawowych narzędzi zachodniej gospodarki. Bazowałaby ona na skonstruowanej politycznie iluzji istnienia nieredukowalnej globalnej nierówności w podziale dóbr, która miałaby być wynikiem cywilizacyjnej wyższości (głównie: technologicznej) Zachodu nad krajami tzw. Trzeciego Świata (,,Tego Innego Świata”31). W tym wypadku głód byłby zjawiskiem pożądanym, sztucznie podtrzymywanym i fałszywie kreowanym jako naturalny/oczywisty problem, który należy zwalczać. Narracja głodu w takim wydaniu jest zatem działaniem czysto propagandowym. Utrzymywanie głodu na świecie w statusie quo okazuje się bowiem niezbędne, jeśli chodzi o efektywne i trwałe uzależnienie mieszkańców Trzeciego Świata od zachodniej humanitarnej dobroczynności i zarazem usprawiedliwianie (w oczach ludzi Zachodu) ich ekonomicznego wyzysku. Ideologia głodu poprzez ową utajoną dystrybucję biedy ${ }^{32}$ dąży więc jednocześnie do wykreowania wizerunku cywilizacji zachodniej jako tej, która poprzez technologiczny postęp i zaawansowaną racjonalizację życia codziennego oraz wypracowanie humanitarnych systemów aksjologiczno-etycznych stanowi niedościgniony wzór dla, zdanej na łaskę i niełaskę natury, nieucywilizowanej reszty świata.

Można by zatem, za Tymoteuszem Karpowiczem, powtórzyć, że „to nie głodni, lecz syci pożerają świat”"33. Jednocześnie chcą ową żarłoczność zataić, ukulturalnić, ukryć pod mitem altruizmu. W ich ślepym głodzie władzy, współistniejącym z głodem technicznej/technologicznej perfekcji ${ }^{34}$, nie ma miejsca na empatię dla głodujących naprawdę. $\mathrm{Ci}$ - nie narzekajac, nie domagając się niczego - plewią w ciszy swoje nieurodzajne ziemie, dziękując zachodnim wybawcom za dar proteinowych batoników ${ }^{35}$.

${ }^{30}$ Zob. np. J. Ziegler, Geopolityka głodu: masowa zagłada, przeł. E. Cylwik, Warszawa 2013; M. Caparrós, Głód, przeł. M. Szafrańska-Brandt, Kraków 2016.

${ }^{31}$ M. Caparrós, dz. cyt., s. 110.

${ }^{32}$ Zob. G.F. Jünger, Perfekcja techniki, przeł. W. Kunicki, Warszawa 2016, s. 29. Jung zauważa wprost proporcjonalną zależność między rozwojem techniki a skalą materialnego ubóstwa wśród społeczeństwa podlegającego mechanizmom technicyzacji. Zdaniem filozofa w rozwój nowoczesnej techniki wpisana jest kapitalistyczna ideologia konsumpcjonizmu opierająca się na nieustannym ruchu podsycania głodu, potęgowania pragnień, modelowania popytu potencjalnych użytkowników/konsumentów wytworów techniki. Jak zauważa: „Maszyna wywołuje wrażenie głodu; to odczucie ostrego, narastającego, nieznośnego głodu wzbudza cały nasz techniczny arsenał". Tamże, s. 54.

${ }^{33}$ T. Karpowicz, *, [w:] tegoż, Dzieła zebrane, t. IV, Wrocław 2013, s. 33.

${ }^{34}$ Określenie Jüngera.

${ }^{35} \mathrm{~Np}$. batonika Plumpy, mającego być antidotum na problem głodu na świecie. Wspomina o nim zarówno Martín Caparrós w Głodzie, jak i bohaterowie spektaklu o tym samym 


\section{Poetyki głodu}

Zostawiając powyższe rozważania nad mechanizmami upolityczniania głodu na marginesie, warto zauważyć, że problem głodu jako taki wyklarował się $e^{36} \mathrm{w}$ Europie Zachodniej i Stanach Zjednoczonych w drugiej połowie XIX wieku ${ }^{37}$, m.in. za sprawa prac Fryderyka Engelsa i Karola Marksa. Znalazło to wyraz w literaturze realistycznej oraz naturalistycznej (spod znaku Balzaka czy Zoli). Głód podlegał wtedy wielopoziomowym analizom prowadzonym w pespektywie przede wszystkim socjologicznej. Stał się zatem istotnym przedmiotem literacko-naukowego dyskursu, lecz $\mathrm{w}$ pełni - jako fenomen wykraczający poza sferę fizjologii i socjologii - zaistniał dzięki Knutowi Hamsunowi i jego psychologicznej powieści Głód (oryg. Sult) sytuującej się na pograniczu naturalizmu i modernizmu.

Co ciekawe, norweskie słowo sult pochodzi od staronordyckiego czasownika soltinn/svelte oznaczającego „marnieć”, „wycieńczyć”. Ten z kolei wywodzi się od pragermańskiego *sweltanq o praindoeuropejskim rdzeniu *swel, czyli „tlić się”, „nie przestać gasnać” ${ }^{38}$. Ta krótka etymologiczna wyprawa nie pozostaje bez znaczenia, wszak wskazuje na nieodłączny komponent znaczeniowy „głodu” ${ }^{39}$, który Hamsun jako pierwszy twórca wysunał na pierwszy plan. Chodzi o pragnieniową strukturę głodu i jego permanentną niezaspokajalność (nieustanne „tlenie się”, niemożność wygaśnięcia). Głównym bohaterem powieści nie jest wszak sam protagonista - pisarz nieustannie poszukujący w Christianii zatrudnienia mogącego zapewnić mu jako taki byt materialny. W dziele Hamsuna to niedający się zaspokoić głód tak naprawdę porządkuje fabułę. Nic znaczącego bowiem poza ciagłą walką pisarza z żywiołem głodu się nie wydarza. Głód nie tylko stanowi więc przedmiot opisu narratora, ale wnika w jego myślenie, w jego język burząc nierzadko zdroworozsądkową logikę opowieści. Słowem, głód staje się obsesyjną siłą, której nie da się ujarzmić dyskursywnie - która wymyka się znaczeniom, próbom racjonalizacji.

tytule (opartym na monografii Caparrósa) wystawianym w Starym Teatrze w Krakowie w reżyserii Anety Groszyńskiej.

${ }^{36} \mathrm{~W}$ znaczeniu: stawania się tematem publicznej debaty oraz społecznej samoświadomości.

${ }^{37}$ Trzeba tu wspomnieć, że niektóre instytucje pomocy humanitarnej powstały już wcześniej, np. Międzynarodowy Ruch Czerwonego Krzyża i Czerwonego Półksiężyca zainicjował swoją działalność w 1856 roku (wtedy jako Międzynarodowy Komitet Pomocy Rannym), jednak zajmowały się one przede wszystkim ofiarami wojen.

${ }^{38}$ Hasło: Sult, [w:] The Bokmål Dictionary, Oslo 2016.

${ }^{39}$ Który obejmuje takie znaczenia, jak: „szczypanie”, „znikanie”, „gaśnięcie” (A. Brückner, Głód, [w:] tegoż, Stownik etymologiczny języka polskiego, Kraków 1927; hasło: Fames, [w:] Stownik tacińsko-polski, oprac. K. Kumaniecki, Warszawa 1986). 
Głód upoił mnie, zataczałem się po prostu [... $]^{40}$ Nie bolało mnie nic, głód przycichł, zamiast tego uczułem miłą pustkę, nie doznawałem wrażeń, rad, że mnie nikt nie widzi [...] $]^{41}$ Głód mnie dręczył, pragnąłem śmierci [...] Głód żarł mnie straszliwy, tak że nie miałem chwili spokoju [... ${ }^{42}$ Nerwowy nastrój pogorszył się, a moja desperacka obrona była daremna. Stałem się łupem najdziwaczniejszych fantazji, koiłem się sam, nuciłem pieśni do snu i potniałem z wysiłku, pragnąć zażyć spoczynku $[\ldots]^{43}$ Szaleństwo moje było to delirium bezsiły i wyczerpania, ale zachowałem pełną świadomośćc 44 .

Trzeba by raczej powiedzieć: narratorowi wydaje się, że zachowuje „pełna świadomość”, łudzi się, że ma kontrolę nad głodem - może przecież w każdej chwili znaleźć kolejne pisarskie zlecenie umożliwiajace na wygaszenie obsesyjnego niepokoju. Czy jednak bohater tak naprawdę dąży do owego spacyfikowania głodowego transu? W jego relacji widoczna jest ambiwalencja doświadczenia głodu, konstytuowana zarówno przez nerwowość, niespokojność, rozdrażnienie, jak i przyjemność (ową „miłą pustkę”), bliskie doznaniom głodu narkotycznego opisywanym czy to w Witkacowskim Nienasyceniu, czy w Nagim lunchu Williama S. Burroughsa kilka dekad później. Widać więc wyraźnie stopniowe przechodzenie od poetyki realistycznej i naturalistycznej znanej z XIX-wiecznych powieści, w których głód traktowany był jako problem przede wszystkim społeczny (był zatem uprzedmiotowiony), do poetyki naturalistyczno-psychologicznej, gdzie najistotniejsze sa psychofizyczne doznania jednostki (głodującego). Stąd tylko o krok do poetyki głodu u podmi otowionego, w której głód zyskuje miano równoprawnego bohatera dzieła, jak dzieje się chociażby w Huśtawce oddechu Herty Müller (2009) ${ }^{45}$. Pomiędzy tymi narracyjnymi sposobami istnienia głodu w tekście lokuje się opowiadanie Franza Kafki Hungerkünstler z 1922 roku. Zakorzenione w polszczyźnie tłumaczenie tytułu miniatury Kafki Głodomór (dosłownie należałoby go tłumaczyć jako Mistrz głodu lub Mistrz głodowania ${ }^{46}$ ) - ewokuje interesujace przesunięcie znaczeniowe słowa „głodomór". Dawniej używało się go na określenie kogoś skrajnie wykończonego z powodu niedoboru pożywienia - „mrącego z głodu” ${ }^{47}$. Dziśs nazywa się tak

${ }^{40}$ K. Hamsun, Gtód, przeł. F. Mirandola, Poznań 2015, s. 55.

${ }^{41}$ Tamże, s. 56.

${ }^{42}$ Tamże, s. 76.

${ }^{43}$ Tamże, s. 54.

${ }_{44}$ Tamże, s. 75.

${ }^{45} \mathrm{~W}$ powieści Müller opowiedziana zostaje historia Oskara Pastiora - rumuńskiego poety, deportowanego po wojnie do radzieckiego obozu pracy. Głównym bohaterem tej historiiwspółtowarzyszem Pastiora (występującego pod nazwiskiem Auberg) staje się ,anioł głodu”.

${ }^{46}$ Takie tłumaczenie zaproponował Łukasz Musiał (F. Kafka, Wybór prozy, oprac. Ł. Musiał, Wrocław 2018).

${ }^{47}$ Zob. hasło: Głód, [w:] A. Brückner, dz. cyt. 
człowieka nad wyraz łakomego, wiecznie niesytego, potrafiącego pochłonąć duże ilości jedzenia. Jeśliby chcieć posłużyć się tą semantyczną rozbieżnością w odniesieniu do bohatera opowiadania Kafki - artysty, którego bezinteresowną ${ }^{48}$ głodówkę podziwiają tłumy - to można by zaryzykować stwierdzenie, że ów Hungerkünstler jest z jednej strony bytem fizycznie zanikającym (,mrącym”) z głodu, z drugiej kimś ciagle nienasyconym - tyle że łaknącym nie pożywienia, a samego procesu głodowania. Byłby więc swego rodzaju metagłodomorem - głodomorem głodu - nigdy w pełni usatysfakcjonowanym ze swojego dzieła (podobnie jak modernistyczny artysta) ${ }^{49}$ :

[...] nikt więc nie mógł stwierdzić na własne oczy, czy rzeczywiście głodował stale i uczciwie; tylko głodomór mógł to wiedzieć, a zatem tylko on mógł jednocześnie być widzem całkowicie zadowolonym ze swego głodowania. On jednak nie był nigdy zadowolony z innego powodu; a może wcale nie z głodowania tak wychudł, że niejeden ku własnemu żalowi musiał omijać pokazy, bo nie mógł znieść jego wido$\mathrm{ku}$, może wychudł na skutek niezadowolenia z samego siebie. On jeden wiedział, poza nim nikt z wtajemniczonych nie wiedział o tym, jak łatwo się głoduje. Była to najłatwiejsza rzecz w świecie ${ }^{50}$.

Łatwość sztuki głodowania ${ }^{51}$ nie polegałaby bynajmniej na braku konieczności posiadania odpowiedniego wykształcenia oraz rekwizytorium - w wypadku mistrza głodowania jedynym instrumentarium jest bowiem ciało artysty, a praktyką twórczą - czynność (albo: bezczynność) nieprzyjmowania posiłków. Łatwość oznacza w tym wypadku brak konkurencji - a przynajmniej domniemanie bycia jedynym na świecie artystą tego fachu.

Trzeba wszak nadmienić, że instytucja mistrza głodowania była niezwykle popularna w Europie końca XIX wieku i pierwszych dekad XX wieku (choć samo opowiadania zaczyna się od stwierdzenia, że: „W ostatnich dziesięcioleciach bardzo osłabło zainteresowanie głodomorami" ${ }^{52}$ ). Bohater opowiadania Kafki zdaje się jednak nieświadomy powszechności swojej profesji, co rozwija

${ }^{48}$ Niemająca charakteru protestu politycznego.

${ }^{49}$ Tym tropem idzie wielu badaczy twórczości Kafki, m.in. Bernd Auerochs, Manfred Engel czy Reiner Stach. Łukasz Musiał podkreśla natomiast aspekt epistemologiczny, pisząc o „niezaspokojonej woli poznania”. Ł. Musiał, Wstęp, [w:] F. Kafka, Wybór prozy..., s. 186. Dodać należy, że zbiór esejów na temat twórczości Kafki (autorstwa m.in. Waltera Benjamina i Mauirice'a Blanchota) zatytułowany został właśnie Nienasycenie (Nienasycenie: filozofowie o Kafce, red. Ł. Musiał, A. Żychliński, Kraków 2011).

${ }^{50}$ F. Kafka, Głodomór, przeł. R. Karst, [w:] tegoż, Opowieści i przypowieści, Warszawa 2016, s. 496-497.

${ }^{51} \mathrm{Na}$ marginesie należy dodać, że instytucja „mistrza głodowania” była faktycznie praktykowana w Europie przełomu XIX i XX wieku. Funkcjonowała często, tak jak w opowiadaniu Kafki, jako atrakcja cyrkowo-jarmarczna (zob. np. P. Payer, Hungerkünstler in Wien. Eine verschwundene Attraktion, Wien 2002).

${ }^{52}$ F. Kafka, Gtodomór, przeł. R. Karst, [w:] tegoż, Opowieści i przypowieści..., s. 494. 
w sztuce/sztuce-szkicu Odejście Głodomora Tadeusz Różewicz: „Głodomór nic nie wie (nie chce wiedzieć) o istnieniu innych głodomorów, żyje tak, jakby był jedynym głodomorem na globie ziemskim. Interesuje go tylko jego głód"53.

Podniesienie głodowania do rangi sztuki $\left(k_{\text {unsztu }}{ }^{54}\right)$ - zatem swoista sublimacja głodu, maksymalne jego ukulturalnienie, nawet jeśli w tonie groteski/makabreski - było możliwe, jak się zdaje, dopiero na gruncie modernizmu. Wcześniej, tj. w nurtach realistyczno-naturalistycznych, głód istniał jako przedmiot nadający się do socjologicznego studium przypadku. U Kafki, wcześniej u Hamsuna, zaczął zyskiwać autonomiczny głos, dlatego pod koniec Hungerkünstlera możliwe jest quasi-dandysowskie wyniesienie ponad wszystko (zwłaszcza ponad okowy natury i filisterskich pseudoprzyjemności) sąd u s maku: „nie mogłem znaleźć potrawy, która mi smakuje. Gdybym ją znalazł, wierzaj mi, najadłbym, najadłbym się do syta, jak ty i wszyscy"55. Powtórzenie tego gestu odnaleźć można w, wydanej pół wieku po opowiadaniu Kafki, powieści Johna Maxwella Coetzeego Życie i czasy Michaela K., której akcja rozgrywa się w pogrążonej w wojnie domowej Republice Południowej Afryki. Jej bohater zapytany o przyczyny rozpoczęcia głodówki oznajmia: „To nie mój rodzaj jedzenia” ${ }^{\circ 6}$.

Bohater opowiadania Kafki dąży więc, z jednej strony, do całkowitego odcieleśnienia, różnicującego go od tłumu sytych gapiów, poddanych tyranii cielesnych żądz („,moje głodowanie ma sens tylko wśród dobrze odżywionych" ${ }^{57}$ ). Jego metapragnienie, czy raczej: antypragnienie (jest to bowiem pożądanie braku jakichkolwiek pragnieńn ${ }^{58}$ ), ma tylko wtedy sens, kiedy istnienie w obecności owych innych „dobrze odżywionych”. Pełnię egzystencji (równoznaczną z redukcją cielesności) osiaga głodomór w momentach największego zainteresowania tłumu. Bez publiczności głodomór egzystencjal-

${ }^{53}$ T. Różewicz, Odejście Gtodomora, [w:] tegoż, Teatr 2, Kraków 1988, s. 292.

${ }^{54} \mathrm{~W}$ wypadku „sztuki głodowania” należałoby mówić raczej o „kunszcie”, jako że „głodomory” pokazywane były najczęściej jako cyrkowe osobliwości (co uwydatnił sam Kafka, umieszczając obok tytułowego Mistrza głodowania trzy inne opowiadania poświęcone właśnie artystom cyrkowym; są to: Pierwsze cierpienie; Mała kobieta i Śpiewaczka Józefina, czyli Naród myszy).

${ }^{55}$ F. Kafka, Głodomór, przeł. R. Karst, [w:] tegoż, Opowieści i przypowieści..., s. 505.

${ }^{56}$ J.M. Coetzee, Życie i czasy Michaela K., [w:] tegoż, W sercu kraju, Życie i czasy Michaela K., Foe, przeł. M. Konikowska, Warszawa 1996, s. 367. W innym miejscu dowiadujemy się z relacji lekarza zwracającego się do bohatera: „Nie chciałeś umrzeć, a jednak umierałeś. Przywodziłeś na myśl króliczka zaszytego w skórę wołu; bez wątpienia się dusiłeś, lecz także łaknąłeś, wśród tylu koszy pełnych mięsa, laknąłeś prawdziwego pożywienia”. Tamże, s. 390.

57 T. Różewicz, dz. cyt., s. 293.

${ }^{58}$ Por. z interpretacją dzieła Kafki autorstwa Gillesa Deleuze'a i Félixa Guattariego, w której to proza autora Procesu funkcjonuje jako maszyna pragnieniowa, gdzie sam akt pisania tożsamy jest z pragnieniem (nie jest zaś uwarunkowany potrzebą ekspresji - wyrażenia treści, jak dzieje się to w przypadku tzw. „wielkiej literatury”). Zob. G. Deleuze, F. Guattari, Kafka. Ku literaturze mniejszej, przeł. A.Z. Jaksender, K.M. Jaksender, Kraków 2016. 
nie zanika, dlatego w końcu musi „odejść” w momencie, gdy jego metasztuka (sztuka dla sztuki) nie jest dostrzegana przez nikogo. Z jednak drugiej strony, zakończenie opowiadania sugeruje iście estetyczny (w znaczeniu: zmysłowy) charakter pragnień głodomora. Czy jego żądza odcieleśnienia nie jest de facto dążeniem do maksymalnej somatyzacji doświadczenia - stania się samym ciałem, przysłowiowymi: skórą i kośćmi? W tym paradoksalnym jadłowstręcie ${ }^{59}$ bohatera dzieła Kafki odsłania się istota głodu jako fenomenu tyleż należącego do natury (cielesności, zmysłów), ile nieuchronnie poddanego kulturowej obróbce (potrzebie sublimacji, np. poprzez sztukę).

Na inny paradoks Mistrza głodowania zwraca uwage Tadeusz Różewicz w swoim dramacie, wkładajac w usta Impresaria takie oto zalecenie dla głodomora: „pasywne głodowanie było dobre przed wojna... teraz trzeba głodować aktywnie, a nawet agresywnie"60. Sama ekspozycja głodu nie jest więc już dla współczesnych ludzi atrakcyjna. Głodujący człowiek w erze „multimedialnego głodu”"61, jak określa to Ewa Lipska w wierszu Układy scalone, nie robi już na nikim wrażenia. Nikt nie zrozumie sztuki głodu, której percepcja opiera się na beznamiętnym i permanentnym kontemplowaniu. „Profesja głodomora" 62 musi wyginać. Kto wie, czy ten fakt, równoznaczny z ostatecznym zniknięciem Kafkowskiego (ostatniego?) głodomora, nie byłby paradoksalnie spełnieniem jego artystycznych marzeń. Tego jednak nie będzie w stanie nikt zaświadczyć. Głód nigdy nie mówi sam za siebie.

\section{Głodne kawałki}

Jakim językiem można jednak pisać o głodzie, żeby nie stał się tylko oderwaną od konkretu metafora ${ }^{63}$ ? Jak sprawić, by zaistniała narracja głodu, nie zaś narracja o głodzie? Innymi słowy: co zrobić, by, mówiąc o głodzie,

${ }^{59}$ Paradoksalnym, bo skupiajacym w sobie zarówno wstręt do tego, co naturalne/fizjologiczne, jak i sublimację (estetyzację) pożywienia. Na temat Kafkowskiej ambiwalencji wstrętu i pożądania pisał m.in. Winfried Menninghaus w Aniele wstrętu - zob. W. Menninghaus, Wstręt. Teoria i historia, przeł. G. Sowinski, Kraków 2009, s. 297-325).

${ }^{60}$ T. Różewicz, dz. cyt., s. 308.

${ }^{61}$ „Na multimedialnym głodzie/włączaliśmy życie./Wyłączaliśmy życie”. E. Lipska, Układy scalone, [w:] tejże, Miłość w trybie awaryjnym, Kraków 2019. Głód multimedialny to głód rozproszony, wirtualny, traktowany jako coś nieistniejącego naprawdę. Por. z rozważaniami Zygmunta Baumana na temat filozofii „nieostateczności”- przekonania o tymczasowości doświadczeń ekstremalnych (takich jak śmierć) - stanowiącej podłoże myślenia ponowoczesnego (Z. Bauman, Płynny lęk, przeł. J. Margański, Kraków 2008).

${ }^{62}$ T. Różewicz, dz. cyt., s. 295.

${ }^{63}$ „Głód to pewna hiperbola, figura wyolbrzymienia. Głód, tak, głód jest czymś najbardziej bezwstydnym, ostatecznym, krzykiem wobec głuchych, metaforą wobec tych, którzy nie chcą słuchać”. M. Caparrós, dz. cyt., s. 668. 
nie produkować kolejnych „głodnych kawałków”, które co prawda brzmią efektownie, lecz nikt nie da im wiary? Czym jest głód „prawdziwy” (niezapośredniczony narracyjnie), o którym pisał Tadeusz Borowski w jednym ze swoich opowiadań (,,Głód jest wtedy prawdziwy, gdy człowiek patrzy na drugiego człowieka jako na obiekt do zjedzenia" $\left.{ }^{64}\right)$ ? W lirycznym cyklu $O$ gtodzie, przywoływany już przeze mnie, Tadeusz Sławek stawia podobne pytania:

Jest mnóstwo ludzi na świecie,

ale tylko jeden głód $\mathrm{d}^{65}$.

Głód nie zna kłamstwa. Niczego nie opowiada ${ }^{66}$.

Opowiada o głodzie tylko ten, co się najadł

i z głodnych kawałków szyje płaszcz sytości.

Nie może być historii głodu [...]

mogą być tylko głodne kawałki ${ }^{67}$.

Jeśli głód jest werbalnie nietranzytywny, jeśli da się o nim pisać tylko niedokładnie, fałszywie, banalnie, to w takim razie, czy „głód” może należeć do sfery kultury, opierającej się wszak na symbolach, znaczeniach, kontekstach, dyskursach etc.? Tadeusz Sławek jest przekonany, że poprzez język nie mamy dostępu do głodu (,Tu mieszka sens. / Głód jest zawsze „tam”68). Niemożliwe jest zatem zarówno prawdziwie empatyczne i rozumiejące wsłuchanie się w opowieści głodu (poprzez relację głodującego), jak i stworzenie satysfakcjonującej opowieści o głodzie. Podążając za myślą Hansa Ulricha Gumbrechta, można by powiedzieć, że głód jako doświadczenie, wobec którego nie da się przejść obojętnie bez poczucia konieczności estetycznego doznania i reakcji na nie, sytuuje się między kultura znaczenia a kulturą obecności, a wiedzieć trzeba, że „napięcie/oscylacja pomiędzy efektami obecności i efektami znaczenia uposaża przedmiot doświadczenia estetycznego w czynnik prowokacyjnej niestabilności i niepokoju" ${ }^{69}$. Czy to nie kolejne powtórzenie pytania o zasadność rozróżnienia między kulturą głodu a natura głodu?

Wydaje się, że z podobnym problemem nieklasyfikowalności i dyskursywnej niewyrażalności głodu oraz związanym z nimi egzystencjalno-estetycznym niepokojem, mierzyła się przywoływana na początku antropolożka Sharman Apt Russell. Badaczka w poszukiwaniu optymalnych narzędzi

${ }^{64}$ T. Borowski, Dzień na Harmenzach, [w:] tegoż, U nas w Auschwitzu...: opowiadania, Warszawa 2001, s. 78.

${ }^{65}$ T. Sławek, Głodne kawatki, [w:] tegoż, dz. cyt., s. 29.

${ }^{66}$ Tamże, s. 30.

${ }^{67}$ Tamże, s. 31.

${ }_{68}$ Tamże, s. 32.

${ }^{69}$ H.U. Gumbrecht, dz. cyt., s. 123. 
legitymizacji swojej opowieści o głodzie poddała swoje ciało czterodniowej głodówce. W czasie postu dokładnie analizowała fizjologiczne zmiany, jakie zachodziły w jej organizmie (m.in. proces ketozy - stan metaboliczny, w którym organizm, na skutek niedostarczania pożywienia, pozyskuje energię z tłuszczu nagromadzonego $\mathrm{w}$ tkankach ${ }^{70}$ ), oraz zwiąane $\mathrm{z}$ nimi reakcje psychologiczne i emocjonalne (np. rozdrażnienie, znużenie). Można domniemać, że przerwanie głodówki nastapiło w momencie, kiedy Russell poczuła, że w jakimś stopniu znalazła rozwiązanie zagadki: co może znaczyć głód (jeśli w ogóle cokolwiek)? Za pozytywną odpowiedź na to pytanie można by uznać samą historię o głodzie, jaką proponuje czytelnikowi amerykańska pisarka. Jednakże zdawkowy komentarz autorki po odbyciu eksperymentalnego postu brzmi jak jeden z kolejnych wariantów „głodnych kawałków”: „Starałam się być uczciwa wobec samej siebie, odpowiadając na pytanie, czemu przerwałam post. Nie pragnęłam już przecie jedzenia. Pragnęłam znaczenia, jakie ono w sobie kryje” ${ }^{71}$. „Byłam znudzona. Zjadłam więc sobie pomarańczę"72 - dodaje badaczka, sugerując, że poniosła poznawcze fiasko.

Wygląda więc na to, że zdani jesteśmy jedynie na „historie” - bajki, przypowieści, anegdoty - o głodzie, które moga jedynie pomóc w naszkicowaniu jego portretu. Russell nazywa swoją opowieść „historią nienaturalną", implikując niejako, że głód pojmuje przede wszystkim jako zjawisko kulturowe (sytuujące się wobec natury). Tadeusz Sławek używa określenia „ludzkozwierzęcy głód”73, wskazując na wspólną doświadczeniu wszystkich, tzw. organizmów wyższych, potrzebę zaspokajania niedoboru pożywienia, która kieruje instynkt przetrwania. Widać więc wyraźnie, że głód jest fenomenem naturokulturowym, którego nie da się podporządkować dychotomicznie tylko jednej kategorii.

Jeśliby znów prześledzić na końcu tego szkicu etymologię „głodu”, to trudno nie zgodzić się z powyższym rozpoznaniem. Polski „głód” pochodzi bowiem od prasłowiańskiego gold- oznaczającego „pragnąć”, ale także „płacić karę", „pokutować”. Łaciński rzeczownik fames, oprócz podstawowego znaczenia („głód”), może także odnosić się do „,niedostatku”, ,żądzy”, czynności „znikania" (ale nie: zupełnego zniknięcia ${ }^{74}$ ) czy - w pochodnej formie - famine do „klęski”. Przodek angielskiego hunger oraz niemieckiego Hunger wskazuje natomiast na krag znaczeń związanych z „paleniem”, „odczu-

\footnotetext{
${ }^{70}$ Hasło: ketosis, [w:] The American Heritage Medical Dictionary, 2007.

${ }^{71}$ S. Apt Russell, dz. cyt., s. 57.

${ }^{72}$ Tamże.

${ }^{73}$ T. Sławek, Wedle głodu, [w:] tegoż, dz. cyt., s. 29.

${ }^{74}$ Por. z analizowanym wcześniej przodkiem norweskiego sult: „tlić się”, „nie przestać gasnące".
} 
waniem”, „szczypaniem” oraz „bólem”75. Jak można zauważyć już po tym pobieżnym etymologicznym rozeznaniu, „głód” semantycznie związany jest przede wszystkim z „pragnieniem”, „niezaspokojeniem”, „nienasyceniem”, które niekoniecznie ma podłoże tylko li fizjologiczne. „Głód” wiąże się także z zagadnieniem kary (za którą trzeba odpokutować, głodując), co zespala go ze sfera religii i polityki/prawodawstwa/kultury (jako zbioru reguł i kar za odstępstwa od nich).

Tym samym oczywiste staje się więc stwierdzenie, że głód nie może być uznawany za zjawisko neutralne/naturalne/oczywiste, traktowane jako coś, czym nie warto się zajmować - jako że jest on udziałem nas wszystkich. W przestrzeni kulturowej komunikacji nie ma głodu czystego, nieopowiedzianego, niepodporządkowanego mechanizmom narracji. Niekiedy głód stanowi centrum kultury (lub formacji kulturopodobnych), gdy jest głównym elementem regulujacym codzienne zachowania oraz utrwalone w społecznej świadomości normy i wartości. Innym razem wykorzystywany jest do celów polityki, będąc poręcznym narzędziem instytucji władzy. Głód może być również tematem/zagadnieniem/problemem - p r ze d mi o t e m lub bohaterem - pod mi o te m - dyskursu artystycznego, stając się jednym z komponentów poetyki dzieła, np. literackiego.

Należy przy tym pamiętać, że, co oczywiste, głodu nie da się w pełni znarratywizować - wypowiedzieć się w jego imieniu (podobnie jak dzieje się, np. z afektami ${ }^{76}$ ). Każda próba uobecnienia głodu w dyskursie antropologicznym, politycznym, artystycznym bądź jakimkolwiek innym wydaje się kolejna nieudana re-prezentacja: chybiona, nienaturalna, czasem przemocowa. Wypada więc stwierdzić, że tak jak n a r r a cja gło du jest konieczna (bo głód domaga się eksplikacji), tak również jest niemożliwa. Czy oznacza to, jedyne, co nam zostaje, to skazane na niepowodzenie rozważania - niedoskonałe narracje o głodzie?

„To głód”, powtarzałem sobie wówczas nieskończoną ilość razy, jakbym chciał samego siebie przekonać, że głód i ja wciąż jesteśmy czymś od siebie różnym i mogę się od niego uwolnić jak od uciążliwego amanta, lecz w rzeczywistości stanowiliśmy pełna bólu jedność i kiedy sobie oświadczałem: „To głód”, to właściwie głód przemawiał, naigrywając się ze mnie ${ }^{77}$.

${ }^{75}$ Zob. hasło: Gtód, [w:] A. Brückner, dz. cyt.; hasło: Fames, [w:] Stownik tacińsko-polski, oprac. K. Kumaniecki, Warszawa 1986, s. 207; hasło: Hunger, [w:] Online Etymology Dictionary, <https://www.etymonline.com/word/hunger>, [dostęp: 21.07.2020].

${ }^{76}$ Zob. Kultura afektu - afekty w kulturze. Humanistyka po zwrocie afektywnym, red. R. Nycz, A. Łebkowska i A. Dauksza, Warszawa 2015.

${ }^{77}$ F. Kafka, Dociekania psa, przeł. L. Czyżewski, [w:] tegoż, Opowieści i przypowieści..., s. 560 . 
Niech klamrą tego szkicu będzie fragment z wiersza poetki, od której utworu zaczałem swoje „dociekania” o głodzie. Wybrzmiewa w nim niezwykle dobitnie (by nie powiedzieć: donośnie) cisza, na jaką skazany jest każdy „narrator” próbujący opowiedzieć głód.

Napisz to. Napisz. Zwykłym atramentem

na zwykłym papierze: nie dano im jeść, wszyscy pomarli z głodu: Wszyscy? Ilu?

To duża taka. Ile trawy

przypadto na jednego? Napisz: nie wiem.

Historia zaokragla szkielety do zera.

$[\ldots]$

Napisz, jaka tu cisza.

$\operatorname{Tak}^{78}$.

\section{BIBLIOGRAFIA}

ŹRÓDŁA LITERACKIE

Borowski T., Dzień na Harmenzach, [w:] tegoż, U nas w Auschwitzu...: opowiadania, Warszawa 2001.

Coetzee J.M., Życie i czasy Michaela K., [w:] tegoż, W sercu kraju, Życie i czasy Michaela K., Foe, przeł. M. Konikowska, Warszawa 1996.

Hamsun K., Głód, przeł. F. Mirandola, Poznań 2015.

Kafka F., Opowieści i przypowieści, Warszawa 2016.

Kafka F., Wybór prozy, oprac. Ł. Musiał, Wrocław 2018.

Karpowicz T., *, [w:] tegoż, Dzieła zebrane, t. IV, Wrocław 2013.

Lipska E., Układy scalone, [w:] tejże, Miłość w trybie awaryjnym, Kraków 2019.

Müller H., Huśtawka oddechu, przeł. K. Leszczyńska, Wołowiec 2010.

Różewicz T., Odejście Głodomora, [w:] tegoż, Teatr 2, Kraków 1988.

Sławek T., O głodzie: wiersze, Katowice 1994.

Swift J., Skromna propozycja, przeł. Ewa Krasińska, „Dialog” 2013, 1.

Szymborska W., Wiersze wybrane, Kraków 2012.

Szymborska W., Wystarczy, Kraków 2012.

OPRACOWANIA

Auerochs B., Ein Hungerkünstler. Vier Geschichten, [w:] M. Engel, B. Auerochs, Kafka-Handbuch. Leben - Werk - Wirkung, Stuttgart, Weimar 2010.

Barnett M., Empire of Humanity: a History of Humanitarianism, London 2011.

Bauman Z., Nowoczesność i zagłada, przeł. F. Jaszuński, Warszawa 1992.

Bauman Z., Ptynny lęk, przeł. J. Margański, Kraków 2008.

${ }^{78}$ W. Szymborska, Obóz głodowy pod Jastem, [w:] tejże, Wiersze wybrane, Kraków 2012, s. $80-81$. 
Camporesi P., Laboratoria zmysłów, przeł. J. Ugniewska, Gdańsk 2005.

Caparrós M., Głód, przeł. M. Szafrańska-Brandt, Kraków 2016.

Deleuze G., Guattari F., Kafka. Ku literaturze mniejszej, przeł. A.Z. Jaksender, K.M. Jaksender, Kraków 2016.

Engel M., Zu Kafkas Kunst- und Literaturtheorie, [w:] M. Engel, B. Auerochs, Kafka-Handbuch. Leben - Werk - Wirkung, Stuttgart, Weimar 2010.

Fames [hasło], [w:] Stownik tacińsko-polski, oprac. K. Kumaniecki, Warszawa 1986.

Foucault M., Czym jest Oświecenie?, [w:] tegoż, Filozofia, historia, społeczeństwo, Warszawa 2000

Głód [hasło], [w:] A. Brückner, Stownik etymologiczny języka polskiego, Kraków 1927.

Gumbrecht H.U., Produkcja obecności: czego znaczenie nie może przekazać, przeł. K. Hoffmann, W. Szwebs, Poznań 2016.

Hamera P., Wielki Głód w Irlandii 1845-1852 w świetle prasy angielskiej, Kraków 2016. Hunger [hasło], [w:] Online Etymology Dictionary, <https://www.etymonline.com/word/ hunger>, [dostęp: 21.07.2020].

Jünger G.F., Perfekcja techniki, przeł. W. Kunicki, Warszawa 2016.

Ketosis [hasło], [w:] The American Heritage Medical Dictionary, 2007.

Kulczycki S., Hołodomor: Wielki Głód na Ukrainie w latach 1932-1933 jako ludobójstwo: problem świadomości, przeł. B. Sałej, Wrocław 2008.

Kultura afektu - afekty w kulturze. Humanistyka po zwrocie afektywnym, red. R. Nycz, A. Łebkowska i A. Dauksza, Warszawa 2015.

Markowski M.P., O reprezentacji, [w:] Kulturowa teoria literatury. Gtówne pojęcia i problemy, red. M.P. Markowski, R. Nycz, Kraków 2006.

Menninghaus W., Wstręt. Teoria i historia, przeł. G. Sowinski, Kraków 2009.

Musiał Ł., Wstep, [w:] F. Kafka, Wybór prozy, Wrocław 2018.

Nienasycenie: filozofowie o Kafce, red. Ł. Musiał, A. Żychliński, Kraków 2011.

Nycz R., Kultura jako czasownik. Sondowanie nowej humanistyki, Warszawa 2017.

Payer P., Hungerkünstler in Wien. Eine verschwundene Attraktion, Wien 2002.

Poetyka egzystencji. Franz Kafka na progu XXI wieku, red. E. Kasperski, T. Mackiewicz, Warszawa 2004.

Riis J., How the Other Half Lives: Studies among the Tenements of New York, Whitefish 2004.

Russell S. Apt, Głód. Historia nienaturalna, przeł. K. Orszulewska, Warszawa 2011.

Stach R., Franz Kafka. Die Jahre der Entscheidungen, Frankfurt am Main 2002.

Sult [hasło], [w:] The Bokmål Dictionary, Oslo 2016.

Ziegler J., Geopolityka głodu: masowa zagłada, przeł. E. Cylwik, Warszawa 2013. 